ERDC TN-19-1

February 2019

\title{
Thin Layer Placement: Technical Definition for U.S. Army Corps of Engineers Applications
}

By Jacob. F. Berkowitz, Candice Piercy, Tim Welp, and Christine VanZomeren

PURPOSE: The following document provides a technical definition of thin layer placement (TLP) activities for U.S. Army Corps of Engineers (USACE) applications. A discussion of the development, history, and examples of TLP applications are also provided.

BACKGROUND: Sediments are routinely intentionally placed into the environment to achieve beneficial outcomes, including beach nourishment, wetland creation, and other activities (Landin et al. 1989; USACE 2015; National Research Council 1995). Many publications and reports document the beneficial use of sediment, including dredged materials, to support infrastructure and enhance ecological outcomes (Yozzo et al. 2004; USEPA and USACE 2007; Faulkner and Poach 1996). Recently, increasing interest has focused on the placement of dredged sediments in thin layers; this provides opportunities for sediment management, beneficial use of dredged material, and ecological restoration or enhancement (Wilbur et al. 2007; Smith and Niles 2016; Berkowitz et al. 2017). Several terms associated with TLP appear in literature (Table 1), highlighting the need for further discussion of the topic and a definition specific to USACE applications.

\begin{tabular}{|l|l||}
\hline \multicolumn{2}{||l||}{ Table 1. Terms associated with TLP within available literature } \\
\hline \hline Term & Source \\
\hline \hline Artificial sediment enhancement & La Peyre et al. 2009 \\
\hline Thin layer placement & USACE, others \\
\hline Thin layer deposition & Ford et al. 1999 \\
\hline Sediment subsidy & Mendelssohn and Kuhn, 2003 \\
\hline Sediment slurry application/addition/amendment & Schrift et al. 2008 \\
\hline Sediment enrichment & Slocum et al. 2005 \\
\hline Thin layer sediment renourishment & Croft et al. 2008 \\
\hline Thin layer disposal & USACE, others \\
\hline Marsh Nourishment & CPRA 2018 \\
\hline \hline
\end{tabular}

BENEFITS OF TLP: In the late 1970s, practitioners began investigating potential benefits of thin layer sediment applications (Reimold et al. 1978). The application of thin layers of sediment may have advantages over traditional, thicker sediment placement applications in a variety of environments where thicker layers of sediment pose potential challenges to natural resources, 
infrastructure, navigation, or other assets. For example, a number of reports document the benefits of thin layer sediment applications such as increased marsh elevation, improved soil stability, and enhancement of wetland functions while maintaining characteristic plant communities (Figure 1) (DeLaune et al. 1990; Mendelssohn and Kuhn 2003). Several studies document the benefits of TLP applications to marsh vegetation, with common wetland plants (e.g., Spartina alterniflora) displaying the capacity for rapid recovery following the deposition of a $0-30 \mathrm{~cm}$ thick layer of sediment. In some cases, the placement of thicker layers of sediment may smother established marsh vegetation, highlighting the benefits of using TLP in some contexts, compared to traditional placement approaches (Riemold et al. 1978). Ray (2007) provides a review of TLP projects conducted in coastal wetlands; however, thin layer applications have occurred in other contexts including open water placement.

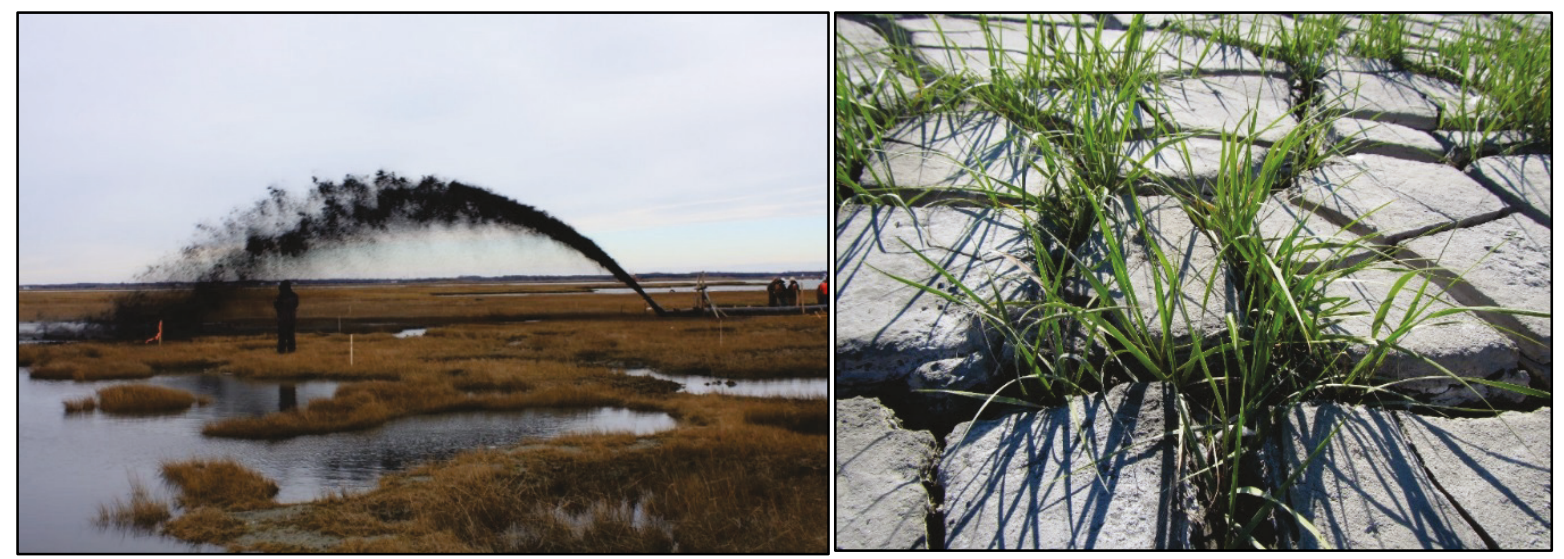

Figure 1. Thin Layer Placement (TLP) of sediment in marsh environments (left) are designed to increase marsh elevation and prevent subsidence, while allowing vegetation to recover (right). Photo credits: Tim Welp (left) and Christine VanZomeren (right).

Open water applications, including TLP on bay bottoms, maintain sediment supplies within the system while enhancing benthic communities (Parson et al., 2015). For example, Wilbur (2007) reported that open water TLP applications resulted in enhanced benthic recovery following dredged material placement at a water depth of approximately $20 \mathrm{~m}$. Others applied TLP to provide supplementary sediment in support of existing infrastructure. This approach was utilized as part of the Mouth of the Columbia River (MCR) Regional Sediment Management Plan, in which the TLP addressed littoral sediment needs by placing sediments to reduce scour along jetties, while avoiding potential negative impacts to navigation safety (e.g., mound elevations) and smothering of biological resources (e.g., fish and crabs) (Figure 2; Portland State University 2016; Roegner and Fields 2014). Alternatively, the practice of capping contaminated sediments with a relatively thin layer of clean dredged material in shallow water at a thickness on the order of the mixing depth of benthic activity may also be referred to as thin layer placement or thin layer capping (Merritt et al. 2010). The use of TLP achieved project objectives while avoiding potential negative impacts to benthic species associated with thicker sediment deposition techniques. 


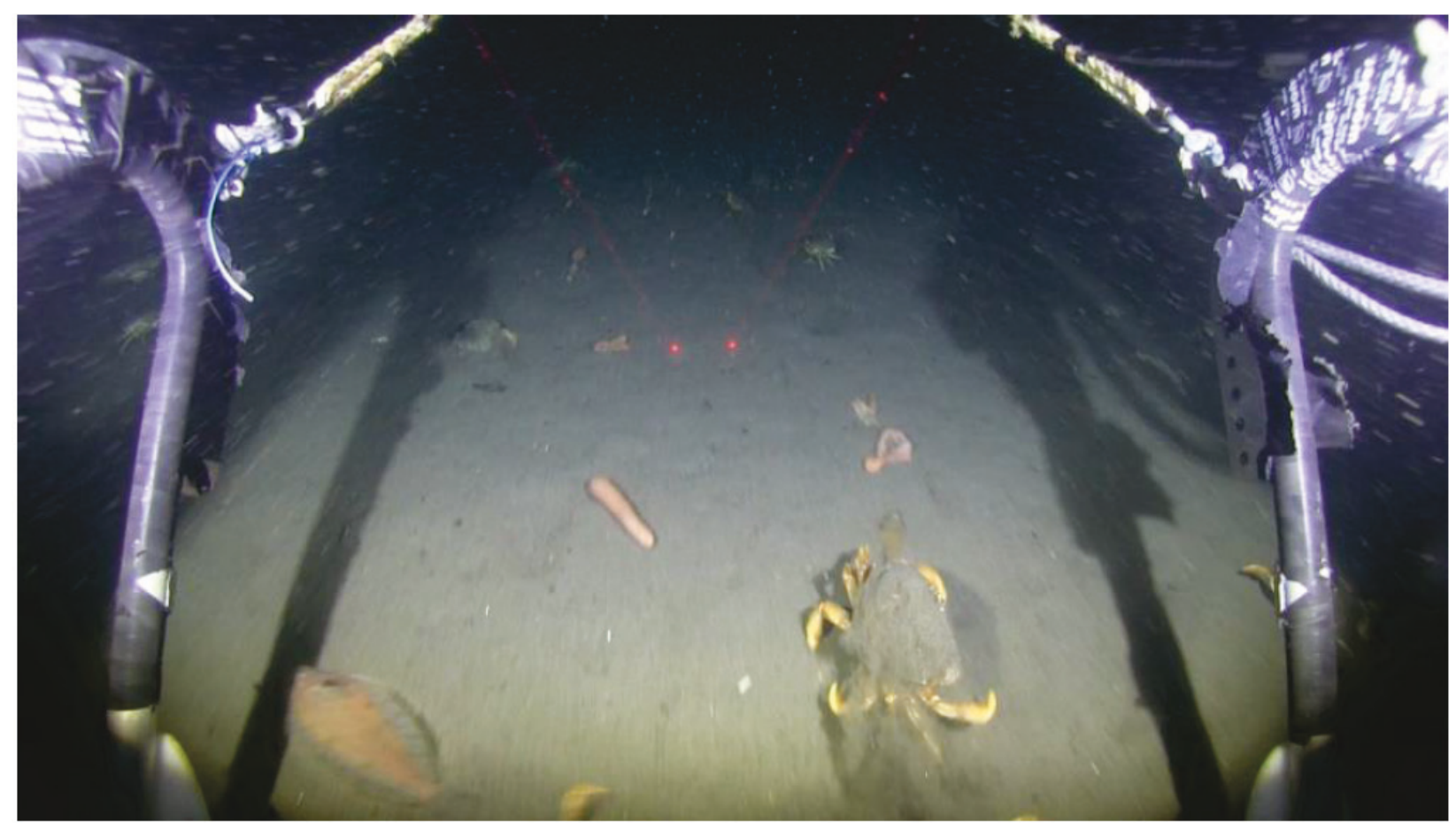

Figure 2. Benthic sled images of fish, worms, and crab emerging from sediment following an open water TLP application within the littoral zone (reproduced from Roegner and Fields 2014).

TLP CHALLENGES: While TLP has proven useful in wetland, subtidal, and open water contexts across the U.S., the wide variety of application methods and project objectives complicate defining the TLP concept (Table 2). Additionally, the ability to obtain a specific TLP thickness or target elevation remains limited by placement technique, equipment, project objectives, and other factors. Specifically, the thickness of material placed by a dredge is a function of the type of dredge equipment being used, how it is being operated, placement site conditions, and dredged material physical characteristics (e.g., dispersion or consolidation potential).

\begin{tabular}{|c|c|c|c|c|}
\hline Location & $\begin{array}{l}\text { Application method } \\
\text { or equipment }\end{array}$ & $\begin{array}{l}\text { Receiving } \\
\text { habitat }\end{array}$ & Depth (cm) & Citation \\
\hline Barataria Basin, LA & Manual spreading & Marsh & $2-5$ & DeLaune et al. 1990 \\
\hline Bayou Lafourche, LA & $\begin{array}{l}\text { Low pressure } \\
\text { discharge }\end{array}$ & Marsh & $13-36$ & Schrift et al. 2008 \\
\hline Blackwater NWR, MD & $\begin{array}{l}\text { High pressure } \\
\text { discharge }\end{array}$ & Marsh & $\begin{array}{l}\text { Target } \\
\text { elevation }\end{array}$ & Nemerson 2007 \\
\hline Blackwater NWR, MD & $\begin{array}{l}\text { High pressure } \\
\text { discharge }\end{array}$ & $\begin{array}{l}\text { Shallow open } \\
\text { water }\end{array}$ & $\begin{array}{l}\text { Target } \\
\text { elevation }\end{array}$ & Nemerson 2007 \\
\hline Coos Bay, OR & Mechanical spreading & Diked marsh & $\begin{array}{l}\text { Target } \\
\text { elevation }\end{array}$ & Cornu and Sadros 2002 \\
\hline Delaware Day, NJ & $\begin{array}{l}\text { High pressure } \\
\text { discharge }\end{array}$ & Diked marsh & $\begin{array}{l}\text { Target } \\
\text { elevation }\end{array}$ & Weinstein and Weishar 2002 \\
\hline
\end{tabular}


ERDC TN-19-1

February 2019

\begin{tabular}{|l|l|l|l|l||}
\hline Location & $\begin{array}{l}\text { Application method } \\
\text { or equipment }\end{array}$ & $\begin{array}{l}\text { Receiving } \\
\text { habitat }\end{array}$ & Depth (cm) & Citation \\
\hline Fortescue, NJ & $\begin{array}{l}\text { Low pressure } \\
\text { discharge }\end{array}$ & Marsh & $\begin{array}{l}\text { Target } \\
\text { elevation }\end{array}$ & Dredging Today 2016 \\
\hline Galveston Bay, TX & $\begin{array}{l}\text { Hydraulic cutterhead } \\
\text { dredge }\end{array}$ & $\begin{array}{l}\text { Open water; } \\
\text { subtidal }\end{array}$ & $7.5-20$ & Sallese 2012 \\
\hline Masonboro Island, NC & $\begin{array}{l}\text { Low pressure } \\
\text { discharge }\end{array}$ & Marsh & $0-10$ & Croft et al. 2006 \\
\hline $\begin{array}{l}\text { Mississippi Sound, } \\
\text { MS }\end{array}$ & $\begin{array}{l}\text { Hydraulic cutterhead } \\
\text { dredge }\end{array}$ & $\begin{array}{l}\text { Open water; } \\
\text { subtidal }\end{array}$ & 15 & Wilber et al. 2007 \\
\hline Mobile Bay, AL & Spill barge & $\begin{array}{l}\text { Open water; } \\
\text { subtidal }\end{array}$ & $<30$ & USACE 2014 \\
\hline Narrow River, RI & Mechanical spreading & Marsh & $10-15$ & USFWS 2014a \\
\hline Pepper Creek, DE & $\begin{array}{l}\text { High pressure } \\
\text { discharge }\end{array}$ & Marsh & $0-20$ & Wilson 2013 \\
\hline Portland, OR & Hopper dredge & $\begin{array}{l}\text { Open water; } \\
\text { subtidal }\end{array}$ & $5-6.8$ & Roegner and Fields 2015 \\
\hline Sachuest Point, RI & Mechanical spreading & Marsh & $2.5-30$ & $\begin{array}{l}\text { Center for Ecosystem Restoration } \\
\text { 2015 }\end{array}$ \\
\hline Seal Beach, CA & $\begin{array}{l}\text { High pressure } \\
\text { discharge }\end{array}$ & Marsh & 25 & USFWS 2014b \\
\hline Venice, LA & $\begin{array}{l}\text { High pressure } \\
\text { discharge }\end{array}$ & Marsh & $2.3 \pm 0.5$ & Ford et al. 1999 \\
\hline Venice, LA & $\begin{array}{l}\text { High pressure } \\
\text { discharge }\end{array}$ & $\begin{array}{l}\text { Shallow open } \\
\text { water }\end{array}$ & $11.6 \pm 1.1$ & Ford et al. 1999 \\
\hline Venice, LA & $\begin{array}{l}\text { Low pressure } \\
\text { discharge }\end{array}$ & Marsh & $0-30$ & Mendelssohn and Kuhn 2003 \\
\hline Vermillion Parish, LA & $\begin{array}{l}\text { Low pressure } \\
\text { discharge }\end{array}$ & Marsh & $0-20$ & Graham and Mendelssohn 2013 \\
\hline \hline
\end{tabular}

* Hydraulic low pressure discharge (modified after Cahoon and Cowan, 1987) consists of an open-ended discharge pipe that is generally equipped with a diffuser (or spreader plate); a device placed to slow the velocity of slurry to provide better control over point placement and/or reduce impacts to wetland surfaces or in the water column.

Hydraulic high pressure discharge involves the use of a contraction section at the pipeline outlet (typically a nozzle) that increases the slurry's exit velocity such that the resultant jetting action propels the slurry in an arc-shaped pattern (some literature sources refer to high pressure discharge applications as "rainbowing"; see Figure 1).

The engineering behavior and physical characteristics of dredged material vary with grain size distribution, organic matter content, mineralogy, and bulk density. In situ sediment is mixed with water in varying proportions, depending on the type of dredging equipment used. For example, mechanical dredges (e.g., clamshell bucket and backhoe) excavate material with near in situ density, while hydraulic pipeline dredging (e.g., cutterhead dredges) typically generate a dredged material slurry with solids content of approximately $15 \%$ by weight. During placement activities, a mechanically dredged, unconsolidated, fine-grained material being released from a dump scow in open water could result in a sediment layer thickness of less than $30 \mathrm{~cm}$, representing a TLP application. However, that same barge filled with a sand-dominated sediment could result in $>200 \mathrm{~cm}$ thick layers of material placed over them same area, eliminating such applications from the TLP by concept. Further, a hydraulically dredged sediment slurry will separate during placement, depositing coarse grained sediment in the immediate vicinity of the discharge point, while the fine-grained sediment spreads and flows further distances (Kungchum et al. 2017). 
Therefore, the deposition layer thickness remains a function of hydraulic sorting processes, including the distance from the discharge location, duration of discharge and quantity of sediment, site topography or containment structure(s), and the density of the deposited material. These factors, along with the variety of project objectives, placement environments, and application techniques, pose challenges to establishing a concise, comprehensive TLP definition. As a result, a review of existing literature was conducted to identify key components defining TLP and synthesize those components related to USACE applications.

DEFINING TLP: Defining TLP promotes clarity for practitioners and the public regarding sediment applications. Additionally, the development of a comprehensive definition provides an opportunity to distinguish TLP from other sediment placement practices, since TLP includes unique application thicknesses, placement techniques, and outcomes (Wilbur 1992; Ray 2007). However, a number of TLP definitions appear in the literature, resulting in confusion regarding the classification and communication of the application, potential benefits, and limitations of this technique. For example, Wilbur (1992) defined TLP as follows:

"Any disposal of dredged material involving the purposeful, planned placement of material at thicknesses that are generally believed to either greatly reduce the immediate impacts to biota or greatly hasten the recruitment of native biota to the material without transforming the habitat's ecological function."

This definition contains several valuable elements, including the fact that TLP activities should remain purposeful and consider potential impacts and benefits to natural resources. However, as written, the definition specifies that TLP applications involve dredged material, potentially excluding other source materials. Additionally, the usage of the term "disposal" has declined in recent years as the scientific community and the public increasingly view dredged materials as a beneficial resource.

LaPeyre et al. (2006) provides the following definition for TLP activities in a marsh nourishment centric context:

"A relatively new restoration strategy that can refer to either the direct placement of a thin-layer of sediment through spray or hydraulic dredging or from the "spilling" of a thin-layer of sediment over marsh that is adjacent to an uncontained restoration project."

This definition also includes several important components, including the potential of TLP to support restoration. However, the definition limits TLP applicability to a particular technique (e.g., spray application) and purpose (e.g., marsh restoration).

The USACE Engineer Research and Development Center (ERDC) Dredging Operations Technical Support (DOTS) program has conducted several TLP-related activities, including the development of a website highlighting TLP concepts, pilot projects, and associated literature (http://tlp.el.erdc.dren.mil/). That resource contains the following definition:

"Thin Layer Placement broadly encompasses the purposeful placement of sediment or dredged material in a manner that produces a specific layer thickness or ground surface elevation necessary 
to achieving the overall project objectives. In TLP projects, the layer thickness typically ranges from a few centimeters to some fraction of a meter, depending upon the variation in ground surface or water levels at the site, and the functional objectives the placement is intended to achieve."

This definition contains many of the positive elements identified by Wilbur (1992), Ray (2007), LePeyre (2006) and others. Additionally, it incorporates the concept of a target elevation as opposed to the sole criterion of a placed thickness.

The following list highlights important components of a comprehensive TLP definition:

- TLP sediment applications should be purposeful.

- TLP sediments should not be limited to dredged material sources.

- TLP projects can support infrastructure objectives.

- $\quad$ TLP activities should be environmentally acceptable.

- TLP projects provide opportunities to create, maintain, enhance, and/or restore ecological function.

- The TLP definition should not specify particular layer thickness or application techniques.

- The term "disposal" should not be incorporated into the TLP definition.

Based on these factors and the previously completed work on the topic, a TLP definition was developed for USACE applications (provided below). This definition incorporates the desirable qualities of prior studies, while making the definition more inclusive and comprehensive to support the wide array of TLP projects being conducted (e.g., open water and marine placement activities). Additionally, the TLP definition may require periodic updates based upon new scientific information and/or advances in TLP practices. Further sub-categorization to address specific types of TLP activities (e.g., marsh vs. open water applications) may be required. Note that the definition is designed to be comprehensive, and intentionally does not specify a threshold thickness. This allows for flexibility based upon habitat (e.g., marsh surface, open water) and project objective (e.g., increase elevation, supplement sediment supply). For example, during marsh nourishment, TLP thickness thresholds are typically dictated by the capacity for vegetation to penetrate the applied sediment layer (Berkowitz et al. 2017). Similarly, in open water settings, TLP thickness may be limited by the ability of benthic organisms to avoid permanent burial (Roegner and Fields 2014). As a result, practitioners should determine and document specific TLP thickness thresholds based upon project specific objectives and site conditions.

TLP DEFINITION: Purposeful placement of thin layers of sediment (e.g., dredged material) in an environmentally acceptable manner to achieve a target elevation or thickness. Thin layer placement projects may include efforts to support infrastructure and/or create, maintain, enhance, or restore ecological function.

SUMMARY: This technical note (TN) current report provides background information regarding TLP, a brief discussion of TLP benefits, and reviews previously published definitions of TLP. 
Based on those findings, a more inclusive, updated TLP definition is presented to support USACE applications.

ACKNOWLEDGEMENTS: This technical note synthesizes information from a number of sources, including the ERDC DOTS 2016 year end In-Progress Review (IPR) meeting held 23-24 August 2016 in Vicksburg, MS. Additional discussions and valuable input was gained during a National Regional Sediment Management (RSM) program workshop held in collaboration with the South Atlantic Division RSM Regional Center of Expertise in Jacksonville, FL, 13-14 December 2016. Discussions related to the development of several products for the Dredging Operations Environmental Research (DOER) program and Environmental Management Restoration Research Program (EMRRP) also contributed to the current report. Linda Lillycrop and Brandon Boyd provided comments on a draft version of this report. Funding for the development and publication of the report was provided by the DOTS and RSM programs.

\section{REFERENCES}

Berkowitz, J. F., C. M. VanZomeren, and C. Piercy. 2017. Marsh restoration using thin layer sediment addition: Initial soil evaluation. Wetland Science and Practice 34(1).

Cahoon, D. R., and J. H. Cowan. 1987. Spray disposal of dredged material in Coastal Louisiana. Baton Rouge, LA: Louisiana State University Louisiana Sea Grant College Program, Center for Wetland Resources.

Center for Ecosystem Restoration. 2015. Maidford saltmarsh restoration draft project description. Wickford, RI: Center for Ecosystem Restoration. Prepared for U.S. Fish and Wildlife Service (USFWS) Rhode Island National Wildlife Refuge Complex.

Coastal Protection and Restoration Authority (CPRA). 2017. Marsh Creation Design Guidelines. Marsh Creation Projects. Report Version. MCDG 1.0.

Cornu, C. E. and S. Sadro. 2002. Physical and functional responses to experimental marsh surface elevation manipulation in Coos Bay's South Slough. Restoration Ecology 10(3):474-486. https://doi.org/10.1046/j.1526100X.2002.01035.x.

Croft, A. L., L. A. Leonard, T. D. Alphin, L. B. Cahoon, and M. H. Posey. 2006. The effects of thin layer sand renourishment on tidal marsh processes: Masonboro Island, North Carolina. Estuaries and Coasts 29:737-750.

DeLaune, R. D., S. R. Pezeshki, J. H. Pardue, J. H. Whitcomb, and W. H. Patrick. 1990. Some influences of sediment addition to a deteriorating salt marsh in the Mississippi River Deltaic Plain: A pilot study. Journal of Coastal Research 6:181-188.

Dredging Today. 2016. Delaware Bay wetlands restored with dredge materials. https://www.dredgingtoday.com/2016/05/23/delaware-bay-wetlands-restored-with-dredge-materials/

Faulkner, S. P., and M. E. Poach. 1996. Functional comparison of created and natural wetlands in the Atchafalaya Delta, Louisiana. WRP-RE-16. Vicksburg, MS. U.S. Army Engineer Waterways Experiment Station.

Ford, M. A., D. R. Cahoon, J. C. Lynch. 1999. Restoring marsh elevation in a rapidly subsiding salt marsh by thinlayer deposition of dredged material. Ecological Engineering 12(3-4):189-205. https://doi.org/10.1016/S09258574(98)00061-5.

Graham, S. and I. Mendelssohn. 2013. Functional assessment of differential sediment slurry applications in a deteriorating brackish marsh. Ecological Engineering 51:264-274. https://doi.org/10.1016/j.ecoleng.2012.12.031.

Kongchum, M, M. D. Materne, G. B. Williamson, and L. Bissett. 2017. Effect of elevation on soil properties in reconstructed back barrier island coastal marsh using dredged materials. Wetlands 37(2):301-311.

Landin, M. C., J. W. Webb, and P. L. Knutson. 1989. Long term monitoring of eleven Corps of Engineers habitat development field sites built of dredged material, 1974-1987. D-89-1. Vicksburg, MS: U.S. Army Engineer Waterways Experiment Station. 
LaPeyre, M., B. Piazza, and B. Gossman. 2006. Short and long-term effects of thin layer deposition of dredged material on marsh health (1434-05HQRU1561, RWO No. 77). Washington, DC: National Marine Fisheries Service (NMFS) - United States Geological Service (USGS) Interagency Agreement No. HC-119. Year 1 Report.

MacArthur, R. 2015. Marshy renewal. Fish and Wildlife News Fall:16-17.

Mendelssohn, I., and N. L. Kuhn. 2003. Sediment subsidy: Effects on soil-plant responses in a rapidly submerging coastal salt marsh. Ecological Engineering 21(2-3):115-128. https://doi.org/10.1016/j.ecoleng.2003.09.006.

Merritt, K. A., J. Conder, V. Kirtay, D. B. Chadwick, and V. Magar. 2010. Review of thin-layer placement applications to enhance natural recovery of contaminated sediment. Integrated Environmental Assessment and Management 6(4):749-760.

National Research Council. 1995. Beach nourishment and protection. Washington, DC: Marine Board Commission on Engineering and Technical Systems. National Research Council Press.

Nemerson, D. 2007. Summary of monitoring data from 2003 wetland restorations at Blackwater National Wildlife Refuge. Baltimore, MD: National Aquarium.

Parson L, N. Lovelace, E. Godsey, K. Reine, and J. Gailani. 2015. Regional sediment management (RSM) Strategy for Mobile Bay, Alabama. ERDC/CHL CHETN-XIV-41. Vicksburg, MS: U.S. Army Engineer Research and Development Center, U.S. Army Corps of Engineers.

Portland State University. 2016. A literature review of the beneficial use of dredged material and sediment management plans and strategies. Portland, OR: Center for Public Service. Mark O. Hatfield School of Government.

Ray, G. L. 2007. Thin layer placement of dredged material on coastal wetlands: A review of the technical and scientific literature. ERDC/EL TN-07-1. Vicksburg MS: U.S. Army Engineer Research and Development Center, U.S. Army Corps of Engineers.

Reimold, R. J., M. A. Hardisky, and P. C. Adams. 1978 The effects of smothering a 'Spartina Alternaflora' salt marsh with dredged material. WES-TR-D-78-38. Vicksburg, MS: U.S. Army Waterways Experiment Station.

Roegner, G. C. and S. A. Fields. 2014. Mouth of the Columbia River beneficial sediment deposition project: Benthic impact study 2014. Seattle, WA: Northwest Fisheries Science Center, National Marine Fisheries Service.

Sallese, C. 2012. Gulf Intracoastal Water Way (GIWW) dredging at West Bay response to public concerns. PowerPoint presentation. Galveston, TX: U.S. Army Corps of Engineers (USACE)-Galveston District.

Schrift, A. M., I. A. Mendelssohn, and M. D. Materne. 2008. Salt marsh restoration with sediment-slurry amendments following a drought-induced large scale disturbance. Wetlands 28:1071-1085.

Slocum, M. G., I. A. Mendelssohn, and N. L. Kuhn. 2005. Effects of sediment slurry enrichment on salt marsh rehabilitation: Plant and soil responses over seven years. Estuaries 28(4):519-528.

Smith, J., and L. Niles. Are salt marsh pools suitable sites for restoration? Wetland Science and Practice 33(4).

U.S. Army Corps of Engineers (USACE). 2014. Letter from Coastal Environmental Team, Planning and Environmental Division to the Alabama Department of Environmental Management.

U.S. Army Corps of Engineers (USACE). 2015. Dredging and Dredged Material Management, Engineer Manual. EM 1110-2-5025. Vicksburg, MS. U.S. Army Corps of Engineers.

U.S. Environmental Protection Agency (USEPA) and U.S. Army Corps of Engineers (USACE). 2007. Identifying, planning, and financing beneficial use projects using dredged material beneficial use planning manual. EPA842B-07-001.

U.S. Fish and Wildlife Service (USFWS). 2014a. Environmental assessment for the Narrow River Estuary resilience restoration program. Charlestown, RI: Rhode Island National Wildlife Refuge Complex.

U.S. Fish and Wildlife Service (USFWS). 2014b. Final initial study/environmental assessment for the Seal Beach National Wildlife Refuge thin-layer salt marsh sediment augmentation pilot project Orange County, California. Chula Vista, CA: San Diego National Wildlife Refuge Complex. 
Weinstein, M. P. and L. L. Weishar. 2002. Beneficial use of dredged material to enhance the restoration trajectories of formerly diked lands. Ecological Engineering 19(3):187-201. https://doi.org/10.1016/S0925-8574(02)00077-0.

Wilber, P. 1992. Thin-layer disposal: Concepts and terminology. Environmental Effects of Dredging Information Exchange Bulletin D-92-1. Vicksburg, MS: U.S. Army Engineer Waterways Experiment Station.

Wilber, D. H., Clarke, D. G. and Rees, S. I., 2007. Responses of benthic macroinvertebrates to thin-layer disposal of dredged material in Mississippi Sound, USA. Marine Pollution Bulletin 54(1):42-52.

Wilson, B. 2013. Rebuilding the wetlands of Pepper Creek: A win-win for boaters and the bays. Inland Bays Journal Spring 2013.

Yozzo, D. J., P. Wilber, and R. J. Will. 2004. Beneficial use of dredged material for habitat creation, enhancement, and restoration in New York-New Jersey Harbor. Journal of Environmental Management, 73(1):39-52.

NOTE: The contents of this technical note are not to be used for advertising, publication, or promotional purposes. Citation of trade names does not constitute an official endorsement or approval of the use of such products. 